\title{
多孔質セラミックを微生物担体とした 嫌気性固定床に上る排水処理
}

\author{
本田繁*・柴 崎和夫**
}

\section{1.はじめに}

嫌気性微生物による排水処理は省エネルギーの観点 から注目を受け研究が進められており，特にてて数年， 産業排水処理に適用しようとする研究が多くなってき た。嫌気性生物処理は, 有機物の分解速度が遅い，好 気性生物処理に比べ有機物の除去率が悪いなどの点を 解決するため, リアクターからの微生物流出を防ぎ， 水理学的帯留時間之無関係に微生物をリアクタ一内に 留め, 微生物濃度を高めて処理効率を高めようとする 気運が高まりつつある。最近検討されている方法は, 菌体フロック分離・濃縮型 1) 2) と菌体固定型に大別さ れる. 菌体固定型には, 有機物ゲルマトリックス内に 菌をとじ込める包括固定法 ${ }^{31}$ ７) と, リアクタ一内に充 填物 (担体)を入れ菌を付着(吸着)固定した嫌気性菌生 物模による方法がある. ${ }^{8 \sim 15)}$ 筆者らは適切な固定化担 体の性状を明らかにするために担体表面と微生物付着 等について報告してきたが, 16) 18) 今回は, 生物膜の発 達に適したサイズにコントロールされた性状を持つ多 孔質セラミックを充填した嫌気固定床による中温メ夕 ン発酵を検討し, 担体の形状と処理性能及び担体形状 と菌体付着性について報告する。

\section{2. 実験方法}

嫌気発酵槽の実験装置を図-1に示す。発酵槽は内径 $40 \mathrm{~mm}$, 高さ $100 \mathrm{~mm}$ (液深約 $80 \mathrm{~mm}$ ) のアクリル製円筒で, その中にセラミック担体を充填した．用いた担体の性 状を表 1 ，担体充塤量を表 2 に示す. 光合成細菌の増 殖を防ぐため発酵槽全体をアルミニウムホイルでカバ 一し，下水処理場の消化污泥を表 3 に示すグルコース， ペプトン系人工下水で馴養したものを種菌として用い,

*工業技術院 大阪工業技術試験所

Shiger u HONDA

**（株）東芝重電技術研究所

Kazuo SHIBAZ AKI
菌を循環させ担体への菌体付着固定を行い，固定化菌 の馴養を兼ねた菌活性試験を約 35 日間行った後連続処 理試験を開始した。連続処理実験条件は，有機物負荷 量を $0.3 \mathrm{~kg} \mathrm{TOC} / \mathrm{m}^{3}$ ・日から $1.4 \mathrm{~kg} \mathrm{TOC} / \mathrm{m}^{3}$ ・日の範 囲で変化させ, HRT（担体充填部のみの空塔滞留時間

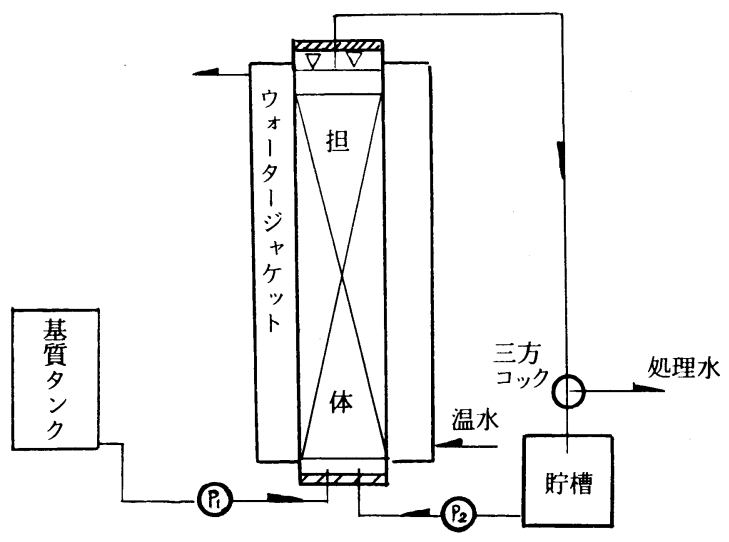

図-1 実験装置フロー

表 1 多孔質セラミックスの性状

\begin{tabular}{|c|cc|c|c|}
\hline 名称 & \multicolumn{1}{|c|}{ 組 } & 織 & $\begin{array}{c}\text { 平均ボアサイズ } \\
\text { (分 布) }\end{array}$ & 気孔率 \\
\hline $\mathrm{A}-4$ & $\begin{array}{l}\mathrm{A} \ell_{2} \mathrm{O}_{3} \\
\mathrm{SiO}_{2}\end{array}$ & $\begin{array}{r}54.3 \% \\
40.7 \%\end{array}$ & $\begin{array}{c}28 \mu \mathrm{m} \\
(1 \sim 60 \mu \mathrm{m})\end{array}$ & $80.1 \%$ \\
\hline $\mathrm{L}-23$ & $\begin{array}{l}\mathrm{A} \ell_{2} \mathrm{O}_{3} \\
\mathrm{SiO}_{2}\end{array}$ & $\begin{array}{l}39.6 \% \\
55.5 \%\end{array}$ & $\begin{array}{c}50 \mu \mathrm{m} \\
(1 \sim 200 \mu \mathrm{m})\end{array}$ & $79.7 \%$ \\
\hline $\mathrm{L}-20$ & $\begin{array}{l}\mathrm{A} \ell_{2} \mathrm{O}_{3} \\
\mathrm{SiO}_{2}\end{array}$ & $42.9 \%$ & $\begin{array}{c}60 \mu \mathrm{m} \\
(4 \sim 150 \mu \mathrm{m})\end{array}$ & $81.6 \%$ \\
\hline
\end{tabular}

表 2 担 体 充 填 量

\begin{tabular}{|c|c|r|r|r|}
\hline $\begin{array}{c}\text { リアクタ } \\
\text { No. }\end{array}$ & $\begin{array}{l}\text { 充填担体 } \\
\text { 名 称 }\end{array}$ & $\begin{array}{c}\text { 担 イ 体 } \\
\text { サ }\end{array}$ & 充填個数 & 充填高さ \\
\hline 1 & $\mathrm{~A}-4$ & $10 \mathrm{~mm}$ 角 & 450 個 & $80 \mathrm{~cm}$ \\
\hline 2 & $\mathrm{~A}-4$ & $15 \mathrm{~mm}$ 角 & 100 個 & $85 \mathrm{~cm}$ \\
\hline 3 & $\mathrm{~L}-23$ & $10 \mathrm{~mm}$ 角 & 450 個 & $83 \mathrm{~cm}$ \\
\hline 4 & $\mathrm{~L}-23$ & $15 \mathrm{~mm}$ 角 & 100 個 & $81 \mathrm{~cm}$ \\
\hline 5 & $\mathrm{~L}-20$ & $10 \mathrm{~mm}$ 角 & 450 個 & $77 \mathrm{~cm}$ \\
\hline
\end{tabular}


表 3 人工排水の組成

\begin{tabular}{|l|r|}
\hline \multicolumn{1}{|c|}{ 分成 } & 単 \\
\hline グルコース $(\mathrm{mg} / \ell)$ \\
ペプトン & 8,000 \\
$\mathrm{KH}_{2} \mathrm{PO}_{4}$ & 3,000 \\
$\mathrm{NaHCO}_{3}$ & 200 \\
$\mathrm{CaCl}_{2} \cdot 6 \mathrm{H}_{2} \mathrm{O}$ & 2,000 \\
$\mathrm{MgSO}_{4} \cdot 7 \mathrm{H}_{2} \mathrm{O}$ & 20 \\
$\mathrm{TOC}$ & 50 \\
\hline
\end{tabular}

により算出） $3 \sim 8$ 時間で行い $37^{\circ} \mathrm{C} \pm 2{ }^{\circ} \mathrm{C}$ 上向流で 表 3 に示す組成の人工下水を所定の濃度にうすめ, 連 続投入し，TOC 除去率等を測定した。

\section{3. 結 果}

\section{1 菌体付着性}

筆者らは先に, 菌体付着性に影響する担体の細孔径, 見掛け空孔率の影響について報告してきたが，今回は， 表 1 亿示すような, 見掛け気孔率 $80 \%$ 程度, 平均細孔 径28 $\mu \mathrm{m}$ から $60 \mu \mathrm{m}$ (あわの部分を除く) $\mathrm{Al}_{4} \mathrm{O}_{3} / \mathrm{SiO}_{2}$ 比 0.71 から1.33の担体を用いて, ポンプ $\mathrm{P}_{2}$ で菌を循環 し, 人工下水を 1 日 1 回投与し, 付着試験を行った結 果を図-2に, 実験終了後付着菌体量を表 4 亿示す。

担体への菌体付着のメカニズムはPertsovskaya et al ${ }^{19)}$, Marshall and Cruickshank ${ }^{201}$ 及び森ら 211 により報告されている．固定化担体の研究としては， Kennedy $^{9)}$ や松山 ${ }^{22)}$, の研究等があり, いずれも, 中 温の嫌気性菌の固定化には表面の荒い材質が有利であ ったてとを報告している．微生物の付着あるいは吸着 の引き金がDLVO理論によるとすれば表面の化学的性 質が大きく左右すると考えられるが，今回実験に供し たセラミックスの主成分はアルミナとシリカであり，

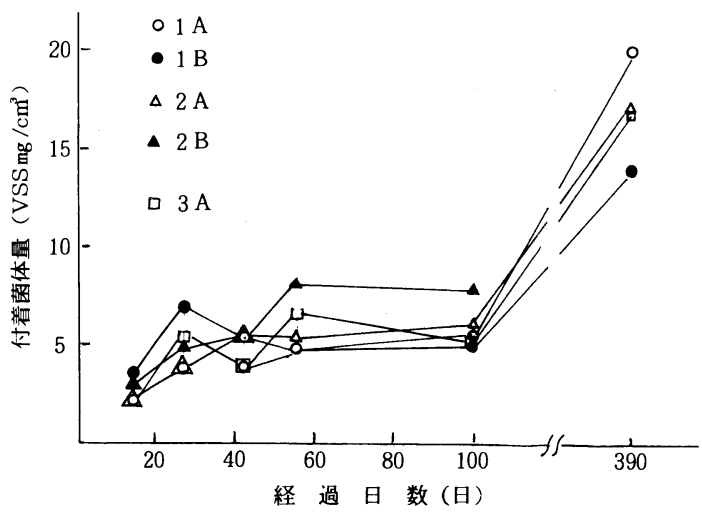

図-2 付着菌体経時変化
表 4 付着 菌 体 量

\begin{tabular}{|c|c|c|c|c|}
\hline 担 体 & 5 名 & $\begin{array}{l}\text { 有効リアクタ } \\
\text { 容 積 }\end{array}$ & 総菌体量 & 菌体濃度 \\
\hline$A-4$ & $10 \mathrm{~mm}$ 角 & $942 \mathrm{ml}$ & $9220 \mathrm{mg}$ & $9790 \mathrm{mg} / \ell$ \\
\hline$A-4$ & $15 \mathrm{~mm}$ 角 & $817 \mathrm{~m} \ell$ & $4650 \mathrm{mg}$ & $5690 \mathrm{mg} / \ell$ \\
\hline LBK-23 & $10 \mathrm{~mm}$ 角 & $930 \mathrm{~m} \ell$ & $7530 \mathrm{mg}$ & $8100 \mathrm{mg} / \mathrm{\ell}$ \\
\hline LBK-23 & $15 \mathrm{~mm}$ 角 & $779 \mathrm{~m} \ell$ & & \\
\hline LBK -20 & $10 \mathrm{~mm}$ 角 & $892 \mathrm{m \ell}$ & $7850 \mathrm{mg}$ & $8800 \mathrm{mg} / \mathrm{\ell}$ \\
\hline
\end{tabular}

このため化学組成の影響はアルミナ, シリカの比率に よると思われるが, アルミナ，シリカ比による影響は 殆んどなかったＶVS の増加からみて30日から40日 程度で担体の表面 (内部表面を除く) への菌体付着が 完了し, 生物膜が形成される。顕徴鏡による観察結果 からも同様のことが認められた，以後除々に担体内部 の細孔表面に菌体が付着し生物膜が形成されていくも のと考えられるが, その速度は初期の担体表面への付 着に比べ遅いことが判った. 担体内部への生物膜の形 成速度の遅い理由は, あわの如く大きな孔径のところ は生物膜による閉塞が起らず基質の供給が十分であり， 菌体量も多く供給されるが，孔径の小さいとてろでは， 孔内部で閉塞あるいは開口部を生物膜で覆われてしま うために, 液相中の基質濃度が全細菌の增殖を支える のに充分なほど高くても, 細孔内間隙に抢いては，乙 の部分に存在する増殖細胞の活発な基質とり込みによ り局部的に基質欠乏状態となる可能性が充分にある. 又菌の付着には液相に分散している菌の量と比例関係 があるが, 細孔の閉塞によって菌が細孔内に到達出来 ないために付着速度が羊くなったものと判断される. また Atkinsonら 23)によれば, biofilm内のすべての 細胞が活性化しているとき, その厚さは通常 70 から 100 $\mu \mathrm{m}$ であるといわれている。一方McCartyら ${ }^{24)}$ によ ると, 酢酸ナトリウムを基質として biofilmを形成す る場合, 酢酸ナトリウム濃度が $0.66 \mathrm{mg} / \ell$ に近づくと フィルムの厚さが急激に減少するてとを見出している. あわの部分で生物膜がよく発達しているてとや，筆者 らの先の報告の結果から biofilmの形成には, $20 \mu \mathrm{m}$ 以下の細孔は無効である。しかし表面の荒い材料が有 利であると云う点では有効であろう．最適孔径は以上 の理由から400 $\mu \mathrm{m}$ から500 $\mu \mathrm{m}$ と判断され，あわの部 分がこれに相当する。

連続処理実験終了後, 担体を取り出し担体内部への 菌体付着性を調べたところ，担体表面から $3 \mathrm{~mm}$ から 5 $\mathrm{mm}$ 程度であり, $15 \mathrm{~mm}$ 角の担体では中心部に菌が付着し 
ておらずデットスペースになっていた．このため $15 \mathrm{~mm}$ 角ではリアクター内の総菌量が少なく処理効率も悪く なった．担体の形状としては一辺 $10 \mathrm{~mm}$ 以下の方形, 球 形または無定形のもので $400 \mu \mathrm{m}$ から500 $\mu \mathrm{m}$ の孔径が 多く空隙率が80\%程度のものが良いと推定される．55 日以後は菌の循環を止め, 基質を一過方式で連続供給 し, 付着菌体の剥離, 菌体活性としてTOC除去率, 処理水の TOC 濃度を調べた結果の一例を図-3に示す. 菌体の洩れはほぶ認められなかったが，№.2のリアク ターで初期に 2 度少量の菌洩れが認められた。乙れは 付着菌が剥離したものと考えるより, 担体の空隙に沈 着していた菌がバイオガスにより搬出されたものと考 えるのが妥当であろう．処理水の TOC は比較的安定 しており菌の活性は十分であると判断される。

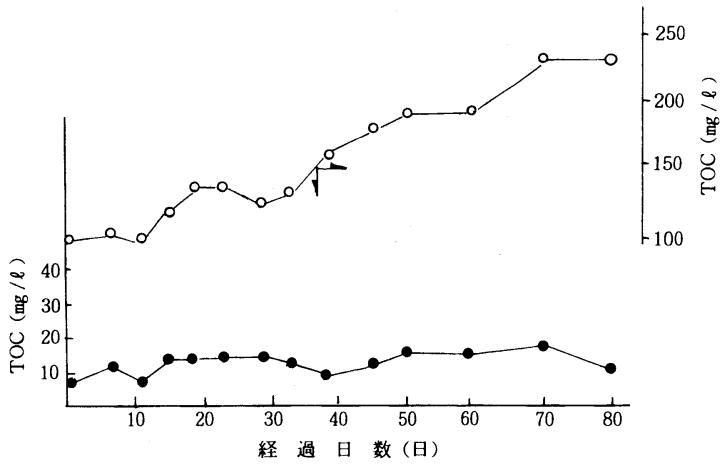

図-3 付着菌活性試験

\section{2 連続処理試験}

菌体付着試験，付着菌活性試験終了後の発酵槽へ基 質濃度を変えて連続投入し，容積負荷を変え，TOC 除 去率への影響，及び基質の投入量を変えて担体充填部 のみの空塔滞留時間( HRT と記す)の影響を調べた結 果を図-4に示す.

HRTが 8 時間以上の場合，処理水の TOC 值は比較 的安定した値を示し, TOC 分解率 屯容積負荷量が0.3 $\mathrm{kg}$ TOC $/ \mathrm{m}^{3}$ ・日から $1.4 \mathrm{~kg} / \mathrm{m}^{3}$ ・日の間ではほとんど 変化がなく，発酵が十分行なわれているととを示して いるが, HRTを低げていき 4 時間以下にすると，容積 負荷量が $0.4 \mathrm{~kg} / \mathrm{m}^{3}$ ・日の軽負荷にかかわらず TOC分 解率は急激に悪くなり, 処理水 $\mathrm{pH}$ も酸性側に移行し て pH 6.5 以下になりメタン生成菌の活性最適 $\mathrm{pH}$ 範囲 から逸脱してくる．先に報告 ${ }^{16)}$ したうに固定床方式 で偏流が生じていると推定されるのと，担体中心部が デットスペースになっているのでHRTに比べ実際の 反応時間 ( RT ) はかなり短かくなっていると推定され る. 特に $15 \mathrm{~mm}$ 角の担体ではその差が大きい。乙のため 加水分解反応, 酸生成反応がメタン生成反応より優位 になり，低級脂肪酸特に酢酸のメタン化率が低下し， $\mathrm{pH}$ が低下したものと考えられる。このことは嫌気性水 処理における菌体高濃度化による処理時間の短縮に限 度があるてとを示唆しているようである。しかし $\mathrm{pH}$

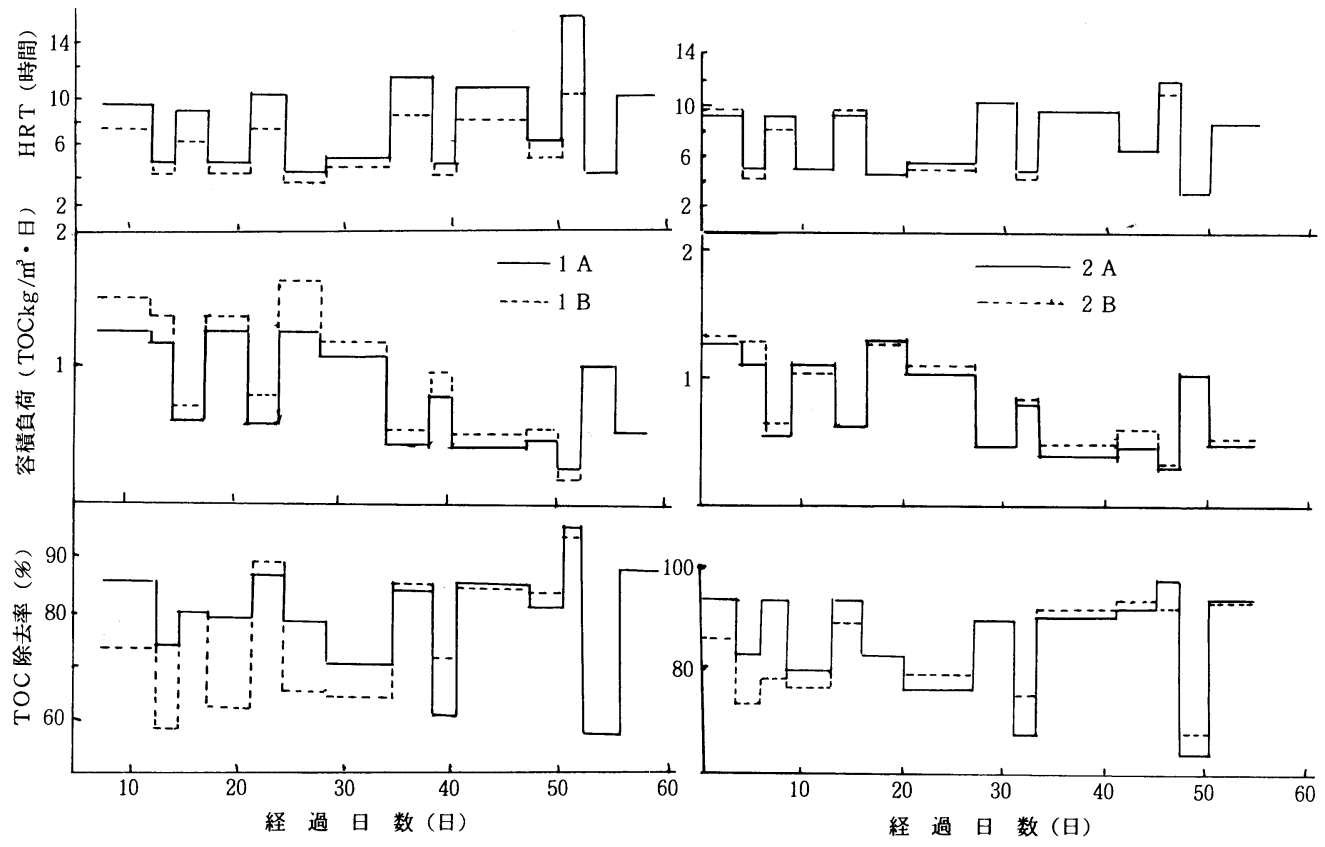

図-4 連 続 試 験 結 果 
5 以下に低下した場合でも,HRTを 8 時間以上にあど すと TOC 除去率は回復するととあに，24時間後の処 理水水質はほぼ正常にもどることから，固定化菌体は $\mathrm{pH}$ 変動に対してかなりの耐性を有している様にみられ る.

生物膜内の基質濃度は, 液相とフィルムの界面で高 く界面から内部に移行する程低くなりフィルム最深部 (担体表面)で最す低くなる。フフィムが活性化を保っ ている厚さの範囲内にあるときは，基質吸収速度はフ ィルムの厚さにほぼ比例することから, 界面から一定 の距離にある点では, 基質拡散速度により基質濃度が 低く，酸生成反応により生成される低級脂肪酸特に酢 酸濃度が低く, メタン生成菌により消費される量と生 成される酢酸等低級脂肪酸量が均衡するため $\mathrm{pH}$ あ変動 せずメタン生成菌の活性阻害を受けない，短時間であ ればメタン生成菌の活性阻害はフィルムの表面近くに とどまっているので，一見 $\mathrm{pH}$ 変動に対する耐性を有 しているようにみえるあのと考える.

一過方式で処理試験を開始して30日目でろから, 槽 内担体の底の部分から白色煭濁物の付着が認められ， 除々に上部一拡大し，120日目でろに最上部まで達した。

基質タンクを腐敗を防ぐため $5{ }^{\circ} \mathrm{C}$ 以下に保っていた が，基質調整24時間後には白濁してくる. 特に外気温 が高い時にその度合が高い，乙の白濁物質が付着した あのと考えられる.乙の白濁物をとって高級脂肪酸, アミノ酸の分析を行ったとてろ, 高級脂肪酸はほとん ど認められず, 高級脂肪酸によるものでないととが判

表 5 白濁物同定試験結果

\begin{tabular}{|c|c|c|}
\hline \multicolumn{3}{|c|}{ T OC変化 } \\
\hline Start & 2 & $271.2(\mathrm{mg} / \mathrm{l})$ \\
\hline Aft. & $2 \mathrm{hr}$ & $219.2(\mathrm{mg} / \mathrm{\ell})$ \\
\hline Aft. & $4 \mathrm{hr}$ & $214.6(\mathrm{mg} / \mathrm{l})$ \\
\hline Aft. & $6 \mathrm{hr}$ & $204.0(\mathrm{mg} / \mathrm{\ell})$ \\
\hline Aft. & $24 \mathrm{hr}$ & $167.5(\mathrm{mg} / \mathrm{l})$ \\
\hline \multicolumn{3}{|c|}{ 生菌数変化 } \\
\hline Start & & $1.7 \times 10^{7}$ \\
\hline Aft & $2 \mathrm{hr}$ & $1.4 \times 10^{7}$ \\
\hline Aft. & $4 \mathrm{hr}$ & $1.3 \times 10_{8}^{7}$ \\
\hline Aft. & $6 \mathrm{hr}$ & $3.7 \times 10^{8}$ \\
\hline Aft & $24 \mathrm{hr}$ & $1.5 \times 10^{8}$ \\
\hline \multicolumn{3}{|c|}{ 酢酸濃度変化 } \\
\hline Start & & $22.8(\mathrm{mg} / \mathrm{l})$ \\
\hline Aft. & $2 \mathrm{hr}$ & $20.5(\mathrm{mg} / \ell)$ \\
\hline Aft. & $4 \mathrm{hr}$ & $8.0(\mathrm{mg} / \mathrm{\ell})$ \\
\hline Aft. & $6 \mathrm{hr}$ & $22.0(\mathrm{mg} / \mathrm{l})$ \\
\hline Aft. & $24 \mathrm{hr}$ & $70.0(\mathrm{mg} / \mathrm{l})$ \\
\hline
\end{tabular}

った.アミノ酸も顕著に認められなかった。 そこで生 菌検查を行ったとてろ表 5 亿示す様な結果がえられた。 てれは增殖したメタン発酵菌群によるものか，基質 に混入した雑菌によるものか現在検討中である.

\section{4. おわりに}

以上の結果より次のてとが明らかになった．

1. 担体表面への生物膜の形成は約30日から40日必要 である。

2. 担体の形状は，20 $\mu \mathrm{m}$ 以下の細孔表面はほとんど有 効にいかされていない，担体の有効細孔径は300 $\mathrm{\mu m}$ 以 上必要である. 大きさは $10 \mathrm{~mm}$ 以上になると内部がデッ トスペースになる可能性が大である。

3. 生物膜は $\mathrm{pH}$ 変動に対する見掛けの耐性はかなり大 きい,

4. 反応時間が短かい之加水分解反応, 酸生成反応が 優先し,メタン生成反応が十分に行われない。

嫌気性生物膜法は種々の濃度の排水に適用が可能で あり，担体により微生物が保持され，微生物の活性を 効果的に作用させられる処理方式の一つと考えられる

最後に, 本研究にで協力下さった(株)東芝重電研究 所の早川, 土田両氏に感謝します.

\section{参考 文 献}

1 ) 原田ら; 衛生工学研究論文集, 21, 153 (1985).

2 ) 遠矢ら；環境技術 16，487，（1987）.

3 ) W. M. Wiegant et al Biotechology and Bioeng 27, 1374, (1985).

4）村上ら; 大工試季報 37, (4)，25，(1986).

5 ) 本田ら; 用水之廃水 29 , ( 8 ), 28, (1987).

6 ) 田中; 第21回水質污濁学会講演集 p 271（1987）.

7 ) 橋本ら; 用水之廃水 $29,(8), 3$ (1987).

8 ) R. E. Speece ; Environ. Sci. Technol 17, (9)416, (1983)

9 ) K. J.Kennedy, et al Biotechna \& Bioeng 27, 86, (1985).

10）黒田；水処理技術 28，347, 455, (1987).

11) 長谷川; 同上 $28,29,(1987)$.

12) K. J. Kennedy et al Journal WPCF 59, 212, (1987).

13）川瀬；噮境技術 16，497（1987）.

14) 堂本ら; 同上 $16,492,(1987)$.

15）石黒ら; 第 2 回生物膜法シンポジゥム論文集p 95 (1987).

16）柴崎ら; 用水之廃水 29,（8） 757 (1987).

17) 本田ら; 水処理技術 28, (2) 69 (1987).

18）本田ら；日化第55秋季年会予稿集 II 3099 p 618 (1987).

19) Pertsovskaya, AF., et al Sov. Soil Sci 4, 684 (1972).

20) Marshall, K. C, et al Arch Mikrobiol., 91, 29 (1973).

21）森, 服部;“界面と微生物”学会出版センタ $-\mathrm{p} 28$ (1986).

22）松山ら; 水質污濁研究 8,（2） 49 (1985).

23) At Kinson, B., et al ; Adv. Biochem. Eng., 3, 221 (1974).

24) P. L Mc Carty et al ; Biotechnol. Bioeng., 22, 2343 (1980). 